\title{
2D Geoelectrical Resistivity Imaging for the Assessment of Subsurface Soil Corrosivity Zones at a Proposed Filling Station Site in Akure Southwestern Nigeria
}

\author{
Alagbe, O.A \\ Department of Applied Geophysics, The Federal University of Technology, Akure - Nigeria
}

\begin{abstract}
Soil corrosion is a serious threat to the integrity of buried structures such as underground storage tank and many other structures. So evaluation of subsurface soil corrosivity using electrical resistivity methods was carried out, with focuses on the assessment of corrosivity probability of the subsurface layers. A shallow geophysical investigation for the corrosivity of subsurface soil at a proposed filling station site in Akure using 2D electrical resistivity imaging profiling was conducted to produce an approximate model of the subsurface resistivity. A total of three horizontal profilings involving the Wenner array 2D imaging was established in the East-West directions of the site investigated and was used to generate 2D pseudosections for the study area. The pseudosection results revealed the corrosivity status of the subsurface soil in the area based on their resistivity values. To further study the corrosive nature of the subsurface soil in the area, a total of thirteen vertical electrical soundings (VES) using modified Wenner array method called specialized engineering spread was used. This method also revealed a three to four earth layer model which the resistivity of the first layers ranging between 23 and $263 \Omega \mathrm{m}$, second layers between 52 and $376 \Omega \mathrm{m}$, the third layers between 37 and $1874 \Omega \mathrm{m}$, while the fourth layers ranges between 470 and $2170 \Omega \mathrm{m}$. The depth ranges for the layers showed that the first layers has a depth range between 0.6 and $1.73 \mathrm{~m}$, the second layers with range between 1.7 and $8.9 \mathrm{~m}$, while the third layers was between 3.9 and $5 \mathrm{~m}$. Columnar sections were also generated to further look into the variations in the resistivity within the depth penetrated. Results obtained from various techniques adopted revealed the suitability of the second and third layers for the burial of the storage metallic tank. But with layer three most suitable
\end{abstract}

Keywords: Electrical resistivity,Corrosivity Isopach map, Geoelectric layer, Steel pipe, Rust

\section{INTRODUCTION}

Electrical resistivity is a fundamental and diagnostic physical property of geologic materials and can be determined by a wide variety of techniques. Its initial use was mainly for hydrogeological, mining and geotechnical investigations, but with increase in environmental awareness and control, its use has now been extended to environmental studies especially to determine the subsurface resistivity distribution in areas requiring subsurface installation of corrosible components.

$[1,2,3]$, emphasis the need to have knowledge of subsurface distribution of resistivity in the construction projects that would involve burial of steel pipe, cables and other subsurface network piping. This becomes more pertinent especially in areas of shallow groundwater condition like Akure where this study was carried out. It has been established that the use of electrical resistivity surveys in environmental studies is derived from the fact that the electrical resistivity of the earth materials depends on environmental parameters such as mineral and fluid content, degree of water saturation in the rock/soil, the amount and concentration of saturating fluids, the conductivity of matrix, porosity, permeability, temperature, grain size and degree of grain cementation $[4,5]$. Knowledge of these will help in proper handling of corrosion problem(s) and increase the design life of steel components and structures. Knowing the range of corrosivity, choices can be made on the kinds of material(s) for subsurface installation and methods of protecting subsurface installation from aggressive subsoil environment, $[6,7,8]$. Therefore the application of geophysics in the investigation of the corrosivity of the earth material prior to subsurface tank laying has become a standard practice in recent times. For any design and corrosion risk assessment purposes, it is desirable to estimate the corrosivity/aggressivity of soils as the knowledge of this is critical for the effective design of cathodic protection measures or predicting the lifetime of a buried steel structure. Since, every civil engineering structure is seated on geological earth materials, it is important to conduct pre-construction investigation of the subsurface of the proposed structures to ascertain the fitness of the host 
earth materials [ 8]. The formation of corrosion cells which can lead to severe corrosion failure in civil engineering structures is known to be associated with low resistivity or high conductivity. Low electrical resistivity is an indicative of good electrical conducting path arising from reduced aeration, increase electrolyte saturation or high concentration of dissolved salts in soils. Generally, the higher the resistivity of the soil, the lower the risk of corrosion.

A major factor in determining soil corrosivity is electrical resistivity. The electrical resistivity of a soil is a measure of its resistance to the flow of electrical current. Corrosion of buried metal is an electrochemical process in which the amount of metal loss due to corrosion is directly proportional to the flow of electrical current from the metal into the soil. Lower electrical resistivities result from higher moisture and soluble salt contents are indicative of corrosive soil $[6,5,8,1]$.

Corrosion is a natural process, which converts a refined metal to a more chemically-stable form, such as its oxide, hydroxide, or sulfide (11). It is the gradual destruction of materials (usually metals) by chemical and/or electrochemical reaction with their environment. Soil corrosion is the deterioration of metal or other materials brought about by chemical, mechanical, and biological action by soil environment (4). Corrosion exists in virtually all materials, but is mostly often associated with metals. Metallic corrosion is a naturally occurring process whereby the surface of metallic structure is oxidized or reduced to a corrosion product such as rust. When the corrosion eventually destroys a sufficient amount of the structure's strength, a failure will occur. Soils constitute the most complex environment known to metallic corrosion. Corrosion of metals in soil can vary from relatively rapid material loss to negligible effects, so soil can be classified as aggressive or non-aggressive, $[2,9]$.

Soil resistivity is the one variable that has the greatest influence on corrosion rate. Though, other factors besides resistivity, such as hydrogen-ion concentration, soluble salts, total acidity are inter-related and is difficult to control conditions so that there is only one variable. In general, the lower the resistivity, the higher the corrosion rate.

So, soil resistivity is one of the factors that closely related to underground corrosion. As soil resistivity becomes lower, groundwater becomes saltier and more conductive, corrosion of a buried metal becomes more severe. It has been noted that soil resistivity is a function of soil moisture and the concentrations of ionic soluble salt, hence it is considered to be the most comprehensive indicator of soil's corrosivity. Many factors such as salinity and nutrients, [ 9], water content and preferential direction of water flow, [8],texture-related properties such as sand, clay, depth of claypans or sand layers, [5] bulk density, [6] and other indirectly measured soil properties such as organic matter, [2] are found to be correlated to soil reistivity. Therefore, soil resistivity is found to be a non-invasive means of measuring and mapping soil properties without intensive sampling campaigns. So soil resistivity represent some major corrosion related soil properties and therefore could serve as a good indicator for soil corrosivity, hence the sole method used in this research work. A correlation between electrical resistivity and soil corrosivity adopted by [8], shall be used for the purpose of corrosivity and lithologic classification in this research work.

Table 1: Classification of soil corrosivity by resistivity [8]

\begin{tabular}{|c|c|}
\hline Soil resistivity (Ohm-m) & Corrosion Rating \\
\hline$<10$ & Extremely Corrosive \\
\hline $10-30$ & Highly Corrosive \\
\hline $30-50$ & Corrosive \\
\hline $50-100$ & Moderately corrosive \\
\hline $100-200$ & Mildly Corrosive \\
\hline$>200$ & Essentially non- Corrosive \\
\hline
\end{tabular}

Table 2: Range of resistivity values and their inferred lithology [8]

\begin{tabular}{|l|l|}
\hline Apparent Resistivity $(\Omega \mathrm{m})$ & Inferred Lithology \\
\hline$<100$ & Clay \\
\hline $100-350$ & Sandy clay \\
\hline $350-750$ & Clayey \\
\hline$>750$ & Sand/Laterite/Bedrock \\
\hline
\end{tabular}

In this study, shallow resistivity measurements were made at locations where it was intended to carry out subsurface installations. The aim was to assess the corrosivity of the sub-soil environment with a view that the survey would give a picture of the subsurface resistivity distribution and suggest the level of aggressiveness of the subsoil environment which can result in corrosion of buried steel components to be installed and the appropriate protection against corrosion to achieve expected design life.

Geophysical electrical surveys with four electrodes configuration such as Sclumberger, Wenner, dipole-dipole, poledipole are being widely used since more than five decades for delineation of geological futures in different geological province [10]. In all these studies mostly vertical electrical sounding (VES) technique has been used. The greatest limitation of such a survey with four electrode configuration is that it provides only $1 \mathrm{D}$ model of resistivity variation 
below the centre of the survey profile and does not take into account lateral changes in the resistivity value on either sides of the centre due to the presence of geological formation/structures such as faults, fractures, joints etc. which are major sources of groundwater in hard-rock formations. Therefore, their delineation by 1D model is not always possible unless these structures coincidentally lie below the centre of the profile. For this particular research work, a more accurate model of the subsurface, a 2D model, using Wenner array which provides information about the resistivity variations in the vertical as well as lateral directions along the survey line has been used together with specialized engineering spread (special Wenner array) for this study. One major advantage of the 2D model is the presentation of images of subsurface litho units along the entire survey line with high resolution. Developments of 2D resistivity models become possible with the development of electrical resistivity tomograph (ERT) technique, which is also known as electrical resistivity imaging. ERT and geotechnical method have been important for environmental and engineering site delineation. With increase in environmental awareness and control, it has now been extended to environmental studies especially to determine the subsurface resistivity distribution in areas requiring subsurface installation of corrosible components [5]. Environmental Impact Assessment (EIA) requires knowledge of subsurface distribution of resistivity in construction projects that would involve burial of steel pipe and cables. The use of electrical resistivity in environmental studies derives from the fact that the electrical resistivity of earth materials (especially soil) depends on environmental parameters such as mineral and fluid content, degree of water saturation in the rock/soil, the amount of concentration of saturating fluids, the conductivity of matrix, porosity, permeability, temperature, grain size and degree of grain cementation.

\section{LOCATION, CLIMATE AND GEOLOGY OF THE STUDY AREA}

The study area is located along Ilesha-Akure Expressway near the Federal University of Technology, Akure Northgate area in Akure South L.G.A of Ondo state, Nigeria. It lies within Northing 808461 to 808507 and Easting 735823 to 735862 (Fig. 1). The area is underlain by the South-Western Precambrian Basement Complex rocks which composed predominantly of magmatic and granitic gneisses, quartzite, slightly migmatised meta-sedimentary schist and metaigneous rocks; charnockite, garbrolic and diorite rocks and the members of the older granite sites, mainly granite, granidiorite and sydenites [12]. Although the basement rock is concealed within the survey area, it is expected to be made up of migmatite gneiss. The elevation above sea level of the study area is between $387 \mathrm{~m}$ and $394 \mathrm{~m}$. The study area is surrounded by evergreen vegetation and it is characterized by two seasons; the wet and dry seasons. The wet season starts around April and ends October with an average annual rainfall of about $1000 \mathrm{~mm}$ to $1700 \mathrm{~mm}$. The dry season starts October starts around November and ends in March. Humidity is relatively high during the wet season and low during the dry season. Temperature varies from $22^{\circ} \mathrm{C}$ to $29^{\circ} \mathrm{C}$.

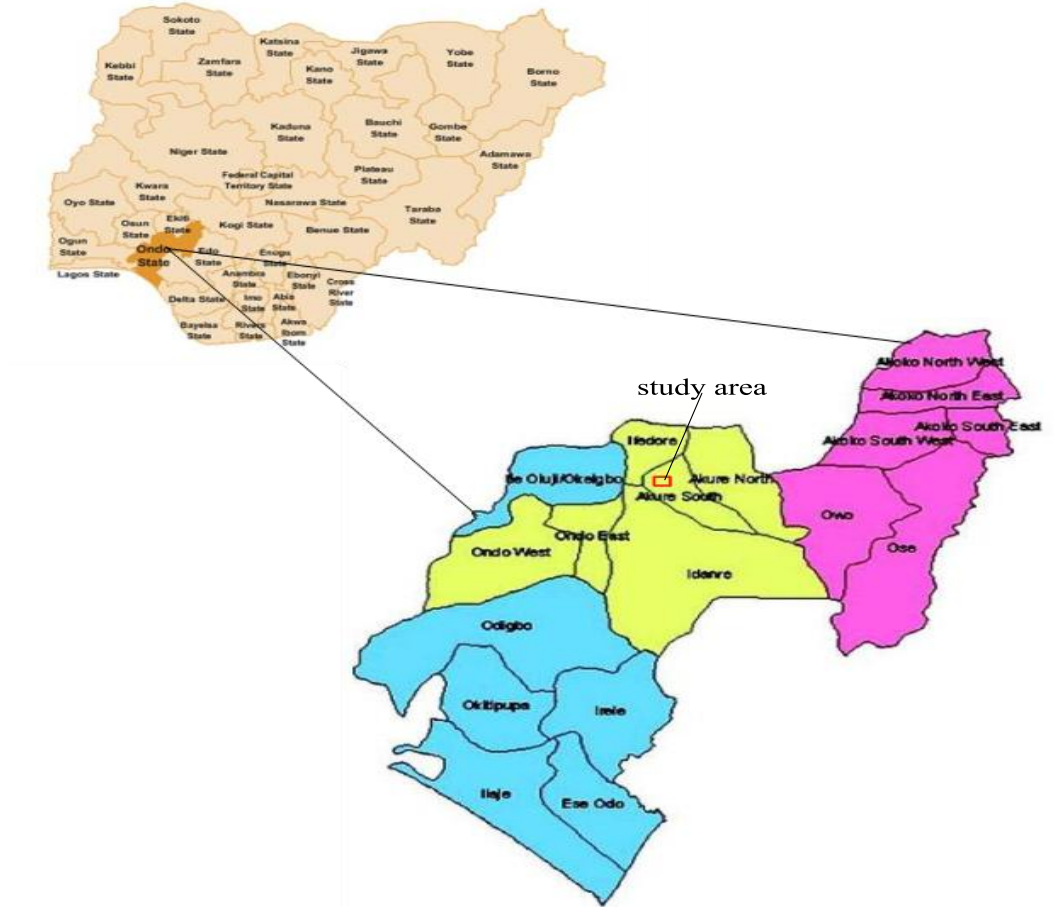

Fig. 1: Location map (Map of Nigeria showing Ondo state and study area) 


\section{International Advanced Research Journal in Science, Engineering and Technology}

Vol. 5, Issue 11, November 2018

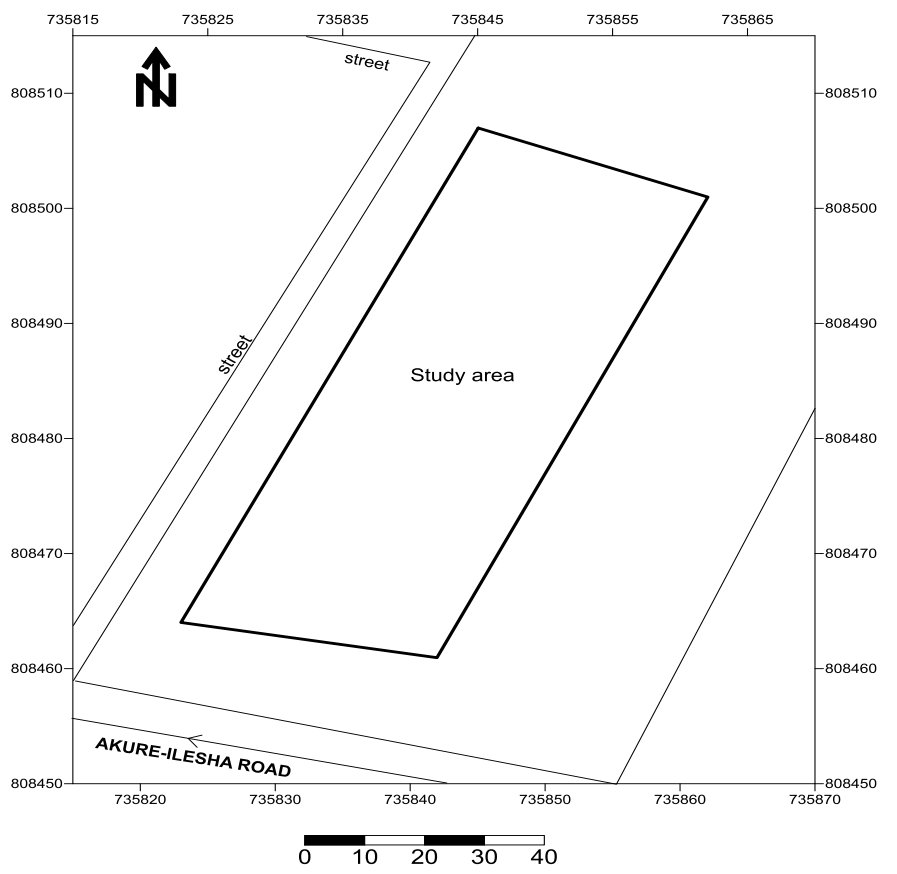

Fig. 2: Base map of the study site

\section{MATERIALS AND METHOD}

In this research work, the Wenner arrays in electrical resistivity survey was adopted. The basic field equipment for this study is the resistivity meter which displays apparent resistivity values digitally as computed from ohm's law. It is powered by a 12 Volt (V) Direct Current (DC) power source. Other accessories to the Resistivity meter include the four metal electrodes, cables for current and potential electrodes, harmers (four), measuring tapes, writing pads. For normal wenner array, three profiles/traverses, which are parallel to each other, were established in East-West direction. Traverse 1 was established at the frontage of study area while Traverse 2 was established in the middle and Traverse 3 was established behind the study area as shown (figure 3 ).

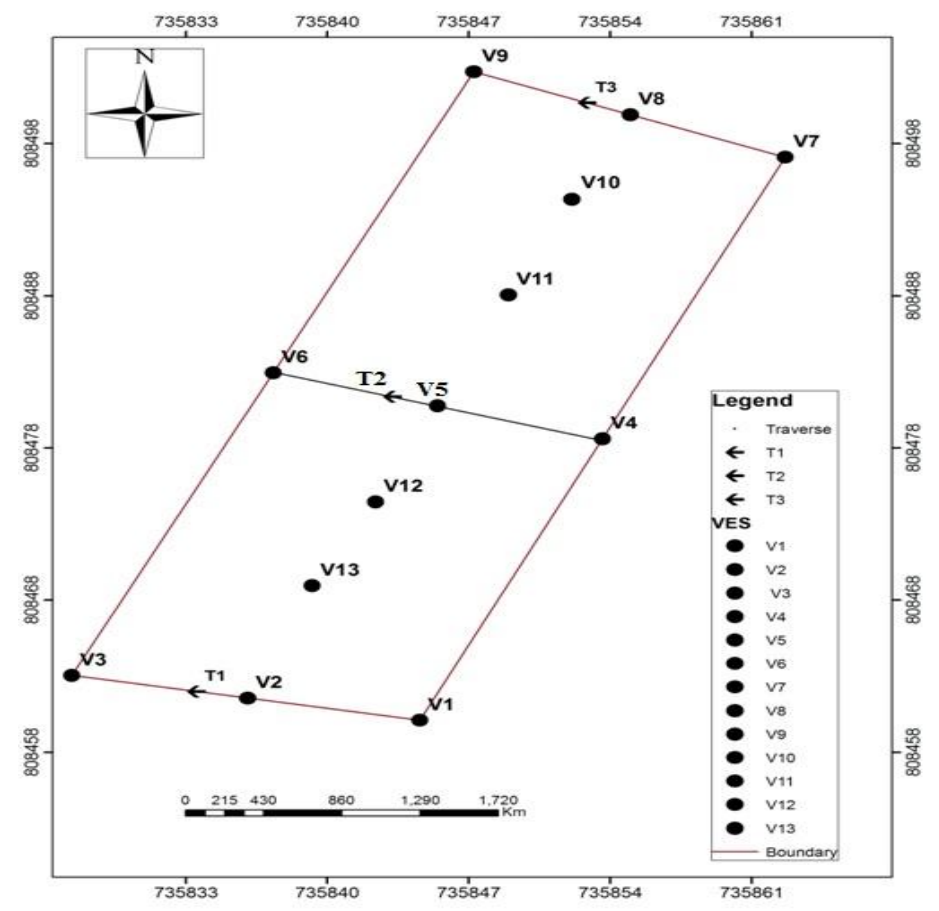

Figure 3: showing the positions of the traverses and VES 
For the specialized engineering spread, a total of thirteen (13) Vertical Electrical Soundings (VES) were established in the study area (Fig.7 ). A maximum of 30m (i.e. maximum of AB of 30) spread was used, starting with 'a' as small as $0.3 \mathrm{~m}$, so as to monitor soil properties to the minimum grain size possible. The data obtained from VES were processed and presented as sounding curves. The geoelectric parameters (resistivity, thickness and depth) obtained were appropriately iterated with the use of a commercial computer program called IPI2WIN VERSION 3.0.1. The program modifies the iteration by inversion mode until a good fit is acquired. Isoresistivity maps, isopach maps and columnar sections were also generated with the aid of SURFER 12 software. The columnar sections showed the subsurface layer resistivities and depths. All the acquired data were processed and subjected to detailed interpretation aimed at determining the subsurface resistivity of the study area. Interpretation of the VES data entails the assessment of the curve types in the study area which quantitatively determines the geoelectric parameters of the subsurface layers in terms of resistivity and thickness (depth). On the basis of the relationship between resistivity and corrosivity, the interpretation and classification of the subsurface lithology was aided through the use of propositions by [8].

\section{REULTS AND DISCUSSION}

\subsection{PSEUDOSECTIONS}

Interpretation of the inverse model resistivity section is done using information obtained from the soil resistivity values of the study area combined with colour range segments of resistivity values encountered in the inverse model resistivity sections for all the profiles investigated in this work, (Fig. 4 to 6), a classification model adopted by [8] was used for the interpretation of the inverse model resistivity section obtained (Table 1). The colour range segment (Table 3) depicts distinct colours, ranging from blue to pupple with blue depicting zones or regions of very low resistivity values (conductive zones) and purple depicting zones of very high resistivity values (high resistive or non-conductive zones).

Table 3: Colour Ratings

\begin{tabular}{|l|l|}
\hline Colour & Resistivity Rating \\
\hline Blue & Very low \\
\hline Green & Low \\
\hline Yellow & Medium low \\
\hline Red & High \\
\hline Purple & Very high \\
\hline
\end{tabular}

Figures 4, 5 and 6 showed the pseudosection plot of apparent resistivity data along traversesT1, T2 and T3. The 2D electrical resistivity section is a reflective of subsurface resistivity along the traverses. The complete set of geoelectrical images (measured apparent resistivity pseudosection (field data pseudosection), calculated apparent resistivity pseudosection (Theoretical pseudosection) and the inverse model resistivity section (2-D resistivity structure) for the profiles are shown in the figures too. The reliability of the inverse model resistivity section is highly reflected in the degree of agreement between the measured and calculated apparent resistivity pseudosections.

Traverse 1 (T1): The 2D electrical resistivity section along T1 is a reflective of subsurface resistivity along the traverse. From stations 2 to 18 at a depth of about $0.5 \mathrm{~m}$ indicating a uniformly very low resistivity zone (blue colour), and between the depth of $0.5 \mathrm{~m}$ to $1.0 \mathrm{~m}$ is another medium resistivity zone (green colour), at between stations 13 and 16 this medium resistivity zone extends downward to a depth of about $2.5 \mathrm{~m}$ toward the eastern part of the traverse. And a low resistivity zone (yellow colour) between stations 3 to 15 at a depth between $1.0 \mathrm{~m}$ to $1.5 \mathrm{~m}$, this zone extends downward to a depth of $5.0 \mathrm{~m}$ at the eastern part of the area (from stations 14). Between stations 4 and 13 at a depth of $2.0 \mathrm{~m}$ to $3.5 \mathrm{~m}$ indicating a high resistive zone (red colour), this zone equally extend to depth of $5 \mathrm{~m}$ from stations 10 toward the eastern part too and between stations 5 to 10 there is a very high resistive zone (purple colour) at a depth of $3.5 \mathrm{~m}$ to $5.0 \mathrm{~m}$ which is the depth of investigation. So from the resistivity section along traverse 1, it showed that two zones are viable for the burial of the tank between stations 4 to 9 at a depth between $2.0 \mathrm{~m}$ to $3.5 \mathrm{~m}(51.9 \Omega \mathrm{m}$ and $84.9 \Omega \mathrm{m})$, and between stations 5 and 10 at depths between 3.5 and $5.0 \mathrm{~m},(63.1 \Omega \mathrm{m}$ and $162 \Omega \mathrm{m})$ along the traverse in the western zone of the traverse. This regions fall within the region that is classified as moderately corrosive and mildly corrosive zones. This region appears to be suitable because of its closeness to a very hard rock or basement, but the tank should be coated with some protective coating materials like bitumen since the area is generally appears to be prone to corrosion and also because it is to be lying on top of a highly fractured basement.

T2: In the 2D electrical resistivity section along T2, from stations 2 to 12 at a depth of 0.0 . to $0.5 \mathrm{~m}$ (blue) is signifying the presence of very low resistivity, between stations 3 and station 11 is indicating a medium low resistivity zone (green colour) at a depth between $0.5 \mathrm{~m}$ to $1.0 \mathrm{~m}$ and a low resistivity zone (yellow colour) between stations 3 to 10 at a 

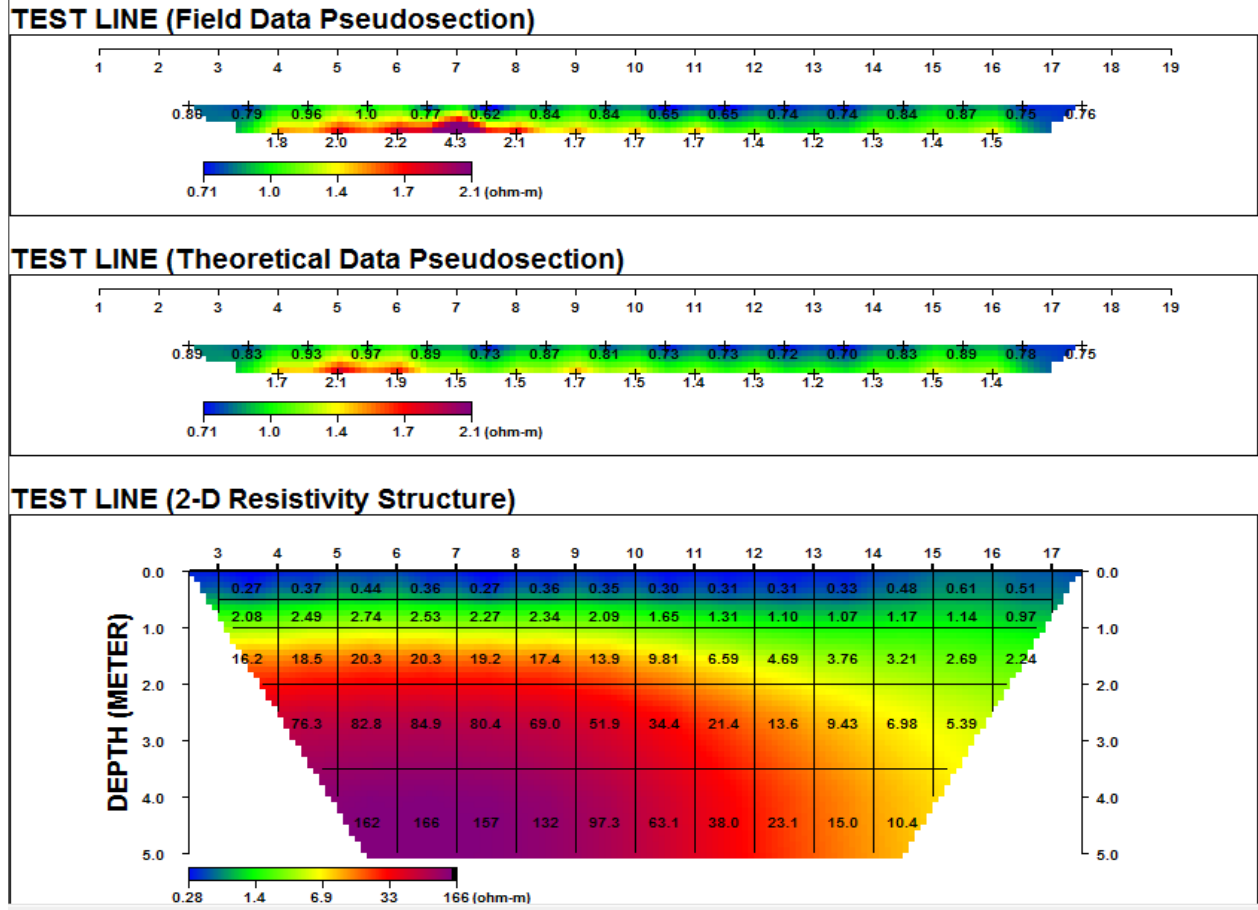

Fig. 4: Showing the pseudosection of T1

depth between $1.0 \mathrm{~m}$ to $1.5 \mathrm{~m}$. Between stations 4 to 10 at a depth between $2.0 \mathrm{~m}$ to $5 \mathrm{~m}$ is an observed presence of high resistivity zone (Red colour). So from the resistivity section along traverse 2 , it showed that there are two viable zones for the burial of the tank between stations 4 to 5 at a depth between $2.0 \mathrm{~m}$ to $3.5 \mathrm{~m}(56.9 \Omega \mathrm{m}$ and $64.6 \Omega \mathrm{m})$ and between stations 5 and 8 at depths between 3.5 and 5.0m $(71.1 \Omega \mathrm{m}$ and $102 \Omega \mathrm{m})$ along the traverse. These two zones also falls within those classified as moderately corrosive mildly corrosive zones. This regions also appears to be suitable because of its reasonable depth as far as shallow engineering study is concerned, but the tank should be coated with some protective coating materials like bitumen since the area is generally appears to be prone to corrosion and also because it is to be lying on top of a highly fractured basement.
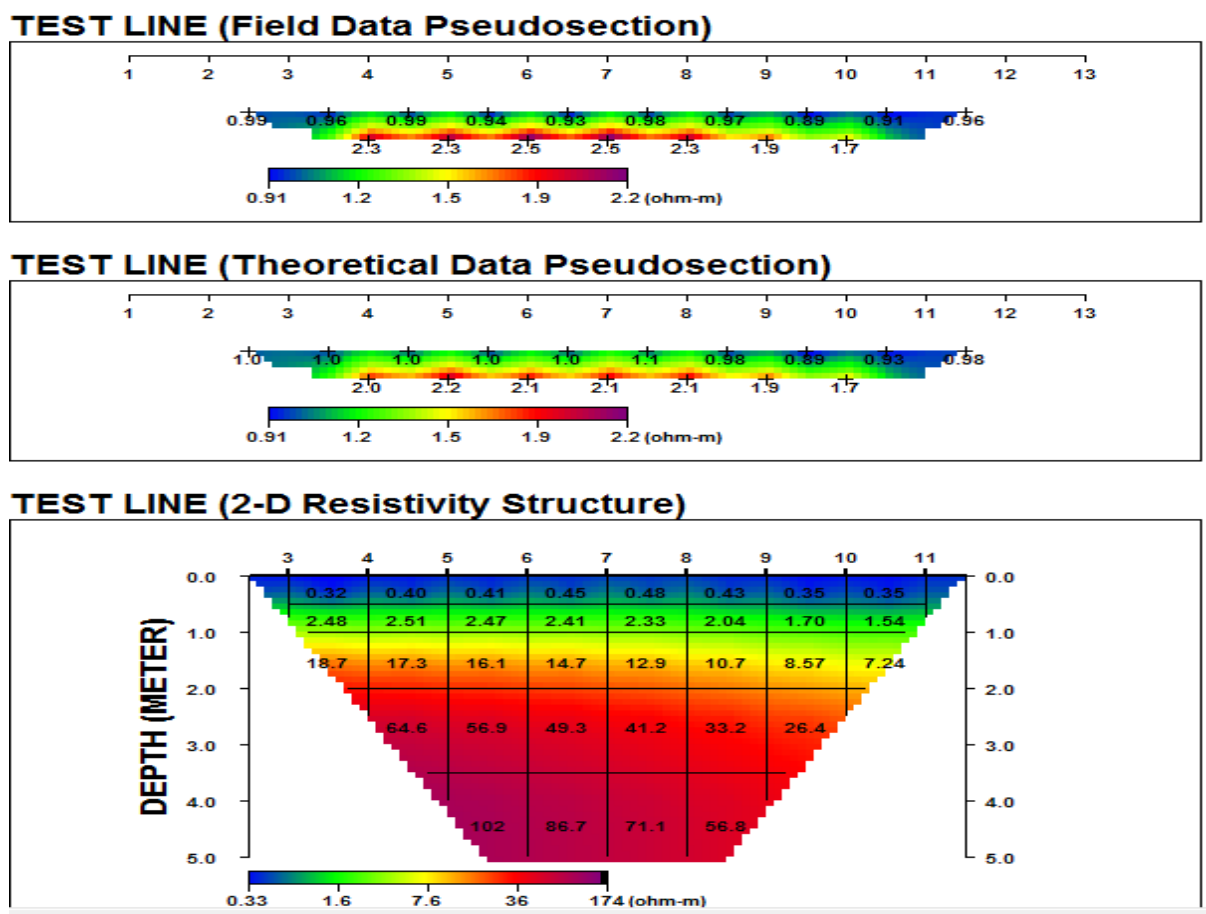

Fig. 5: Showing the pseudosection of T2 
T3: In the $2 \mathrm{D}$ electrical resistivity section along T3, from station 2 to 12 at a depth of $0.0 \mathrm{~m}$ to $0.5 \mathrm{~m}$ (blue) is signifying the presence of very low to low resistivity, between station 3 and station 11 is indicating a medium low resistivity zone (green colour) at a depth between $0.5 \mathrm{~m}$ to $1.0 \mathrm{~m}$ and a low resistivity zone (yellow colour) between stations 4 to 10 at a depth between $1.0 \mathrm{~m}$ to $1.5 \mathrm{~m}$. Between stations 4 to 10 at a depth between $1.5 \mathrm{~m}$ to $5 \mathrm{~m}$ is a presence of high resistivity zone (Red colour). So from the resistivity section along traverse 3, it showed that there are two viable zones for the burial of the tank between stations 4 to 5 at a depth between $2.0 \mathrm{~m}$ to $3.5 \mathrm{~m}(555.0 \Omega \mathrm{m}$ and $63.2 \Omega \mathrm{m})$ and between stations 5 and 8 at depths between 3.5 and $5.0 \mathrm{~m}(66.6 \Omega \mathrm{m}$ and $99.8 \Omega \mathrm{m})$ along the traverse. The two zones falls within those classified as moderately corrosive zones. This region also appears to be suitable, but the tank should equally be coated with some protective coating materials like bitumen since the area is generally appears to be prone to corrosion and also because it is to be lying on top of a highly fractured basement.

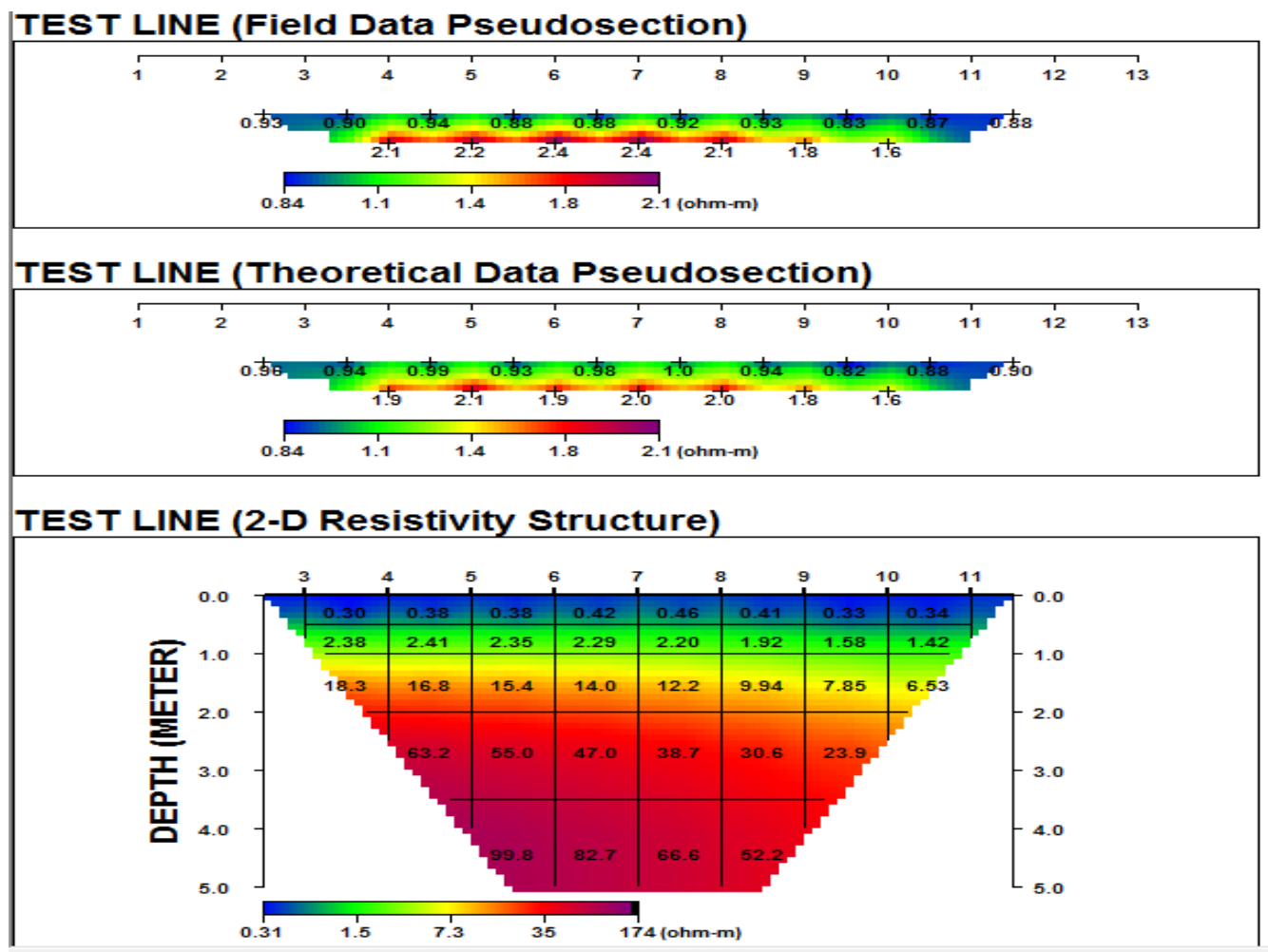

Fig. 6: Showing the pseudosection of T3

\subsection{VERTICAL ELECTRICAL SOUNDING (VES)}

The results of the sounding curves from the computer iteration showed that the site under investigation exhibit a 3-4 geoelectric layers down to the depth investigated by the maximum current electrode used (fig.7) The summary of the VES results, inferred lithology and the corresponding corrosivity status were as depicted in table 4

The first layers of the VES curves has resistivity values ranging between 23 and $263 \Omega$ m, comprising of top soils with depth values between 0.2 and $1.73 \mathrm{~m}$. The first layer which is the top soil and for the kind of engineering work expected at the site, that is the burial of a metallic tank, it has to be excavated aside the fact that depth values might be too shallow for such an engineering work.

The second layers have also, resistivity values between 52 and $376 \Omega \mathrm{m}$, while their depth values also ranges between 1.7 and $8.9 \mathrm{~m}$. These layers fall within corrosive and mildly corrosive zones, with lithologies between clay, sandy clay and clayey sand. Anywhere along these layers of the VES points appears to be favourable for the burial of the tank, with the exception of VES points 1,5,6, 7 and 11 where their depths may be a drawback in terms of either too shallow (VES1;1.7m, VES6; 1.7m) or too deep (VES5; 8.7m, VES7;7.4m and VES11; 6.3m).

The third layers have their resistivities between 37 and $1874 \Omega \mathrm{m}$, while the depths range between 4 and $5 \mathrm{~m}$. The layers lies within corrosive and mildly corrosive zones, and the soil type or lithology suspected within the zone are clay and sandy clay. So in terms of depth and corrosivity status, layer 3 is most favourable zone for the burial of the tank. This VES results correlates well with the results obtained from the $2 \mathrm{D}$ pseudosections, where it was also revealed that a depth of between 2 and $5 \mathrm{~m}$ be recommended and also in agreement with oral interview conducted from owners of some filling stations around the site of investigation,who confirmed depths between 2.5 and $5 \mathrm{~m}$ for the burial of their tanks.

Table 3:Summary of VES model parameters,inferred lithology and corrosivity status 
International Advanced Research Journal in Science, Engineering and Technology

Vol. 5, Issue 11, November 2018

\begin{tabular}{|c|c|c|c|c|c|c|}
\hline VES & NO. of layers & $\begin{array}{l}\text { Resistivity } \\
(\Omega \mathrm{m})\end{array}$ & Thickness (m) & Depth (m) & $\begin{array}{l}\text { Inferred } \\
\text { Lithology }\end{array}$ & $\begin{array}{l}\text { Corrosivity } \\
\text { Status }\end{array}$ \\
\hline \multirow[t]{4}{*}{1} & 1 & 49 & 0.6 & 0.6 & Top soil & - \\
\hline & 2 & 153 & 1.13 & 1.7 & Sandy clay & $\begin{array}{l}\text { Mildly } \\
\text { corrosive }\end{array}$ \\
\hline & 3 & 71 & 3.27 & 5 & Clay & $\begin{array}{l}\text { Moderately } \\
\text { corrosive }\end{array}$ \\
\hline & 4 & 470 & -- & -- & Clayey sand & $\begin{array}{l}\text { Essentiall } \\
\text { non-corrosive }\end{array}$ \\
\hline \multirow[t]{3}{*}{2} & 1 & 214 & 1.73 & 1.73 & Top soil & - \\
\hline & 2 & 65 & 3.39 & 5.1 & Clay & $\begin{array}{l}\text { Moderately } \\
\text { corrosive }\end{array}$ \\
\hline & 3 & 382 & -- & -- & Clayey sand & $\begin{array}{l}\text { Essentially } \\
\text { non-corrosive }\end{array}$ \\
\hline \multirow[t]{3}{*}{3} & 1 & 198 & 1.73 & 1.73 & Top soil & - \\
\hline & 2 & 87 & 3.27 & 5 & Clay & $\begin{array}{l}\text { Moderately } \\
\text { corrosive }\end{array}$ \\
\hline & 3 & 210 & -- & -- & Sandy clay & $\begin{array}{l}\text { Essentially } \\
\text { non-corrosive }\end{array}$ \\
\hline \multirow[t]{3}{*}{4} & 1 & 263 & 0.43 & 0.4 & Top soil & - \\
\hline & 2 & 121 & 2.98 & 3.4 & Sandy clay & $\begin{array}{l}\text { Mildly } \\
\text { corrosive }\end{array}$ \\
\hline & 3 & 108 & -- & -- & Sandy clay & $\begin{array}{l}\text { Mildly } \\
\text { corrosive }\end{array}$ \\
\hline \multirow[t]{3}{*}{5} & 1 & 23 & 0.24 & 0.24 & Top soil & - \\
\hline & 2 & 124 & 8.7 & 8.9 & Sandy clay & $\begin{array}{l}\text { Mildly } \\
\text { corrosive }\end{array}$ \\
\hline & 3 & 507 & -- & -- & Clayey sand & $\begin{array}{l}\text { Essentially } \\
\text { non-corrosive }\end{array}$ \\
\hline \multirow[t]{4}{*}{6} & 1 & 50 & 0.6 & 0.6 & Top soil & - \\
\hline & 2 & 156 & 1.13 & 1.7 & Sandy clay & $\begin{array}{l}\text { Mildly } \\
\text { corrosive }\end{array}$ \\
\hline & 3 & 72 & 3.37 & 5 & Clay & $\begin{array}{l}\text { Moderately } \\
\text { corrosive }\end{array}$ \\
\hline & 4 & 469 & -- & -- & Clayey sand & $\begin{array}{l}\text { Essentially } \\
\text { non- } \\
\text { corrosive }\end{array}$ \\
\hline \multirow[t]{3}{*}{7} & 1 & 34 & 0.28 & 0.28 & Top soil & - \\
\hline & 2 & 104 & 7.14 & 7.4 & Clay soil & $\begin{array}{l}\text { Mildly } \\
\text { corrosive }\end{array}$ \\
\hline & 3 & 663 & -- & -- & Clayey sand & $\begin{array}{l}\text { Essentially } \\
\text { non-corrosive }\end{array}$ \\
\hline \multirow[t]{4}{*}{8} & 1 & 85 & 0.85 & 0.85 & Top soil & - \\
\hline & 2 & 364 & 1.38 & 2.2 & Clayey & $\begin{array}{l}\text { Essentially } \\
\text { non-corrosive }\end{array}$ \\
\hline & 3 & 43 & 1.91 & 4.1 & Clay & Corrosive \\
\hline & 4 & 2170 & -- & -- & Bedrock & $\begin{array}{l}\text { Essentially } \\
\text { non-corrosive }\end{array}$ \\
\hline 9 & 1 & 85 & 0.9 & 0.9 & Top soil & - \\
\hline
\end{tabular}


International Advanced Research Journal in Science, Engineering and Technology

Vol. 5, Issue 11, November 2018

\begin{tabular}{|c|c|c|c|c|c|c|}
\hline & 2 & 361 & 1.4 & 2.2 & Clayey sand & $\begin{array}{l}\text { Essentially } \\
\text { non-corrosive }\end{array}$ \\
\hline & 3 & 41 & 1.8 & 4 & Clay & Corrosive \\
\hline & 4 & 1835 & -- & -- & Bedrock & $\begin{array}{l}\text { Essentially } \\
\text { non-corrosive }\end{array}$ \\
\hline \multirow[t]{3}{*}{10} & 1 & 26 & 0.2 & 0.2 & Top soil & - \\
\hline & 2 & 52 & 1.97 & 2.2 & Clay & $\begin{array}{l}\text { Moderately } \\
\text { corrosive }\end{array}$ \\
\hline & 3 & 118 & -- & -- & Sandy clay & $\begin{array}{l}\text { Mildly } \\
\text { corrosive }\end{array}$ \\
\hline \multirow[t]{3}{*}{11} & 1 & 25 & 0.6 & 0.6 & Top soil & - \\
\hline & 2 & 69 & 5.7 & 6.3 & Clay & $\begin{array}{l}\text { Moderately } \\
\text { corrosive }\end{array}$ \\
\hline & 3 & 1874 & -- & -- & Bedrock & $\begin{array}{l}\text { Essentially } \\
\text { non-corrosive }\end{array}$ \\
\hline \multirow[t]{3}{*}{12} & 1 & 30 & 0.3 & 0.3 & Top soil & - \\
\hline & 2 & 52 & 1.9 & 2.2 & Clay & $\begin{array}{l}\text { Moderately } \\
\text { corrosive }\end{array}$ \\
\hline & 3 & 120 & -- & -- & Sandy clay & $\begin{array}{l}\text { Mildly } \\
\text { corrosive }\end{array}$ \\
\hline \multirow[t]{4}{*}{13} & 1 & 83 & 0.9 & 0.9 & Top soil & - \\
\hline & 2 & 376 & 1.3 & 2.2 & Clayey sand & $\begin{array}{l}\text { Essentially } \\
\text { non-corrosive }\end{array}$ \\
\hline & 3 & 37 & 1.7 & 3.9 & Clay & Corrosive \\
\hline & 4 & 1517 & -- & -- & Bedrock & $\begin{array}{l}\text { Essentially } \\
\text { non-corrosive }\end{array}$ \\
\hline
\end{tabular}

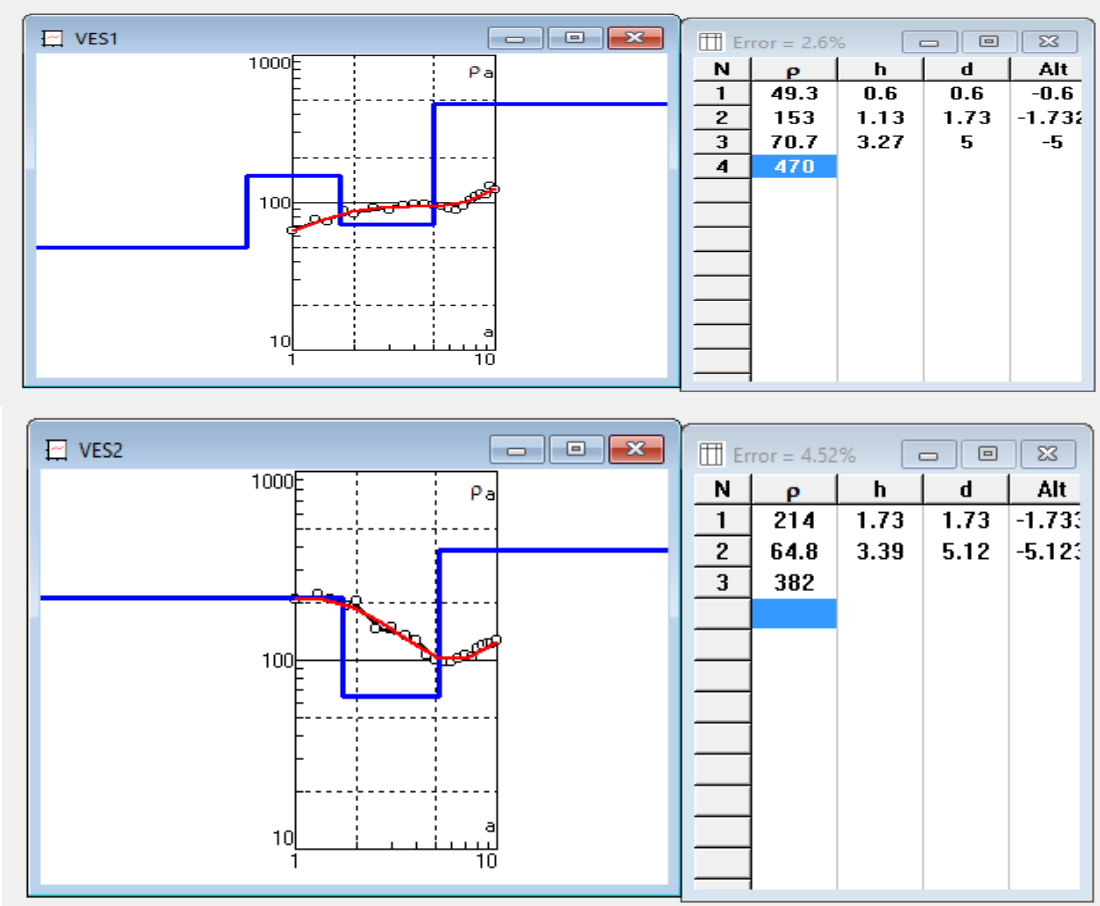


International Advanced Research Journal in Science, Engineering and Technology

Vol. 5, Issue 11, November 2018
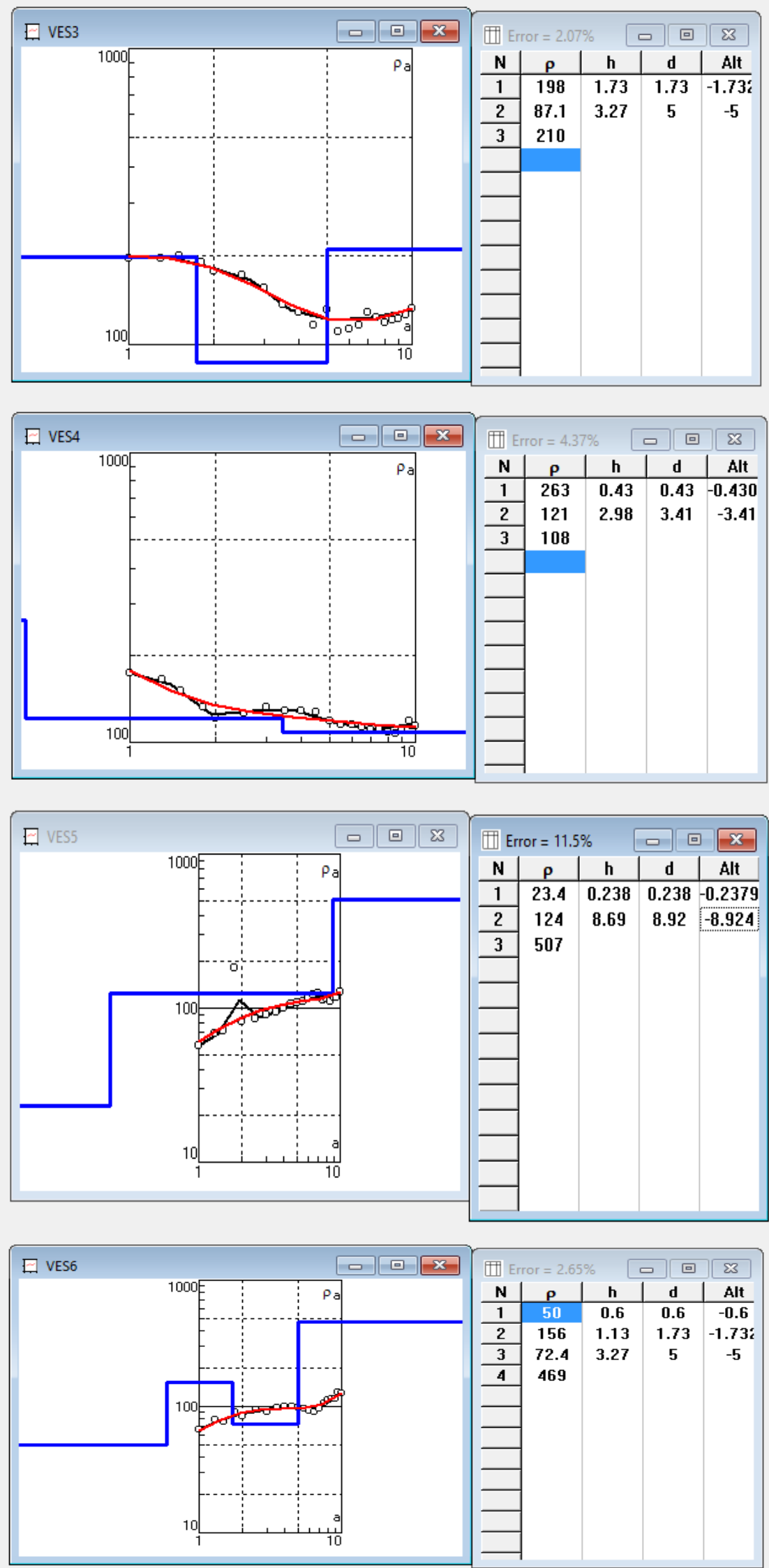


\section{International Advanced Research Journal in Science, Engineering and Technology}

Vol. 5, Issue 11, November 2018
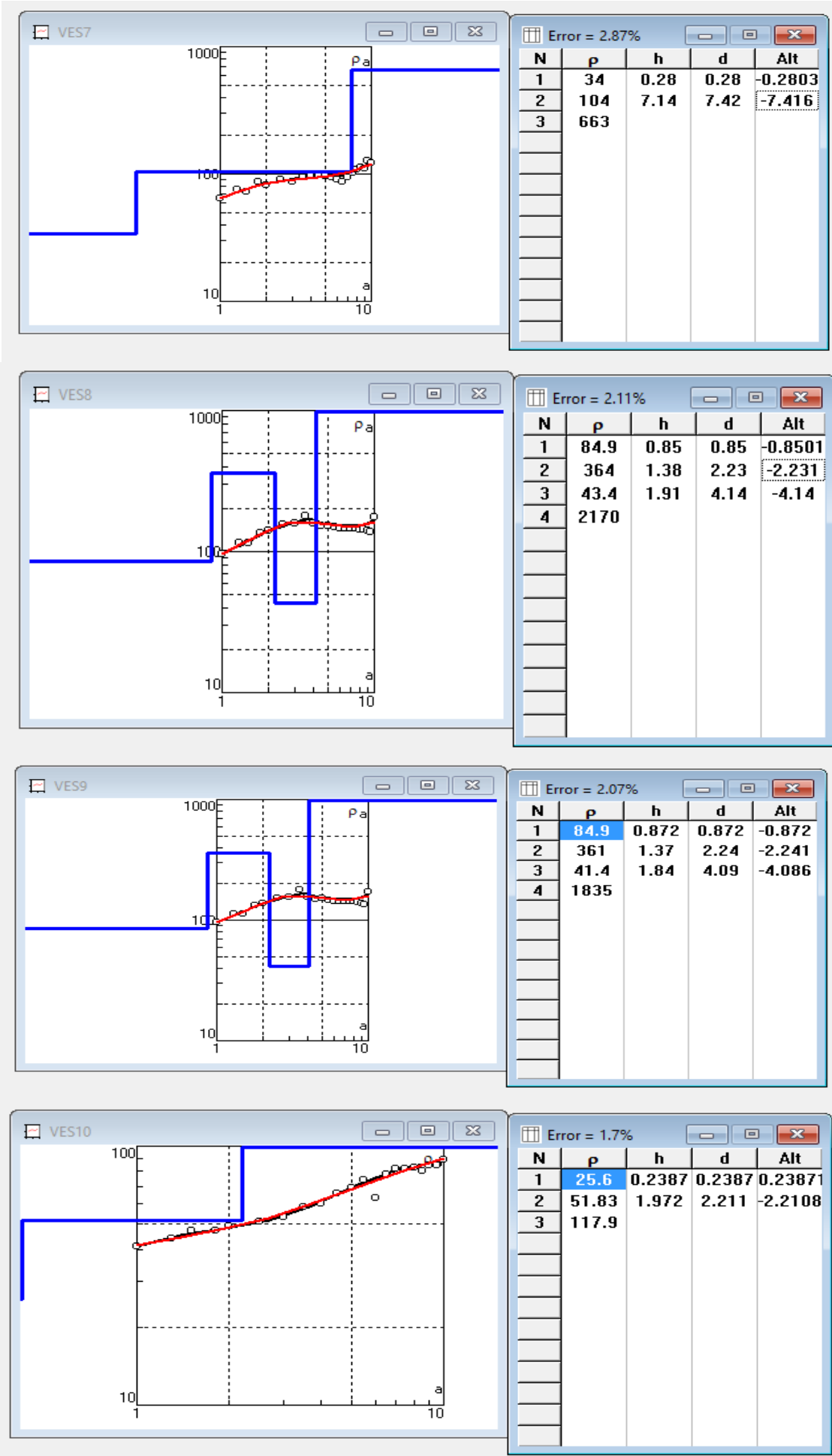


\section{International Advanced Research Journal in Science, Engineering and Technology}

Vol. 5, Issue 11, November 2018

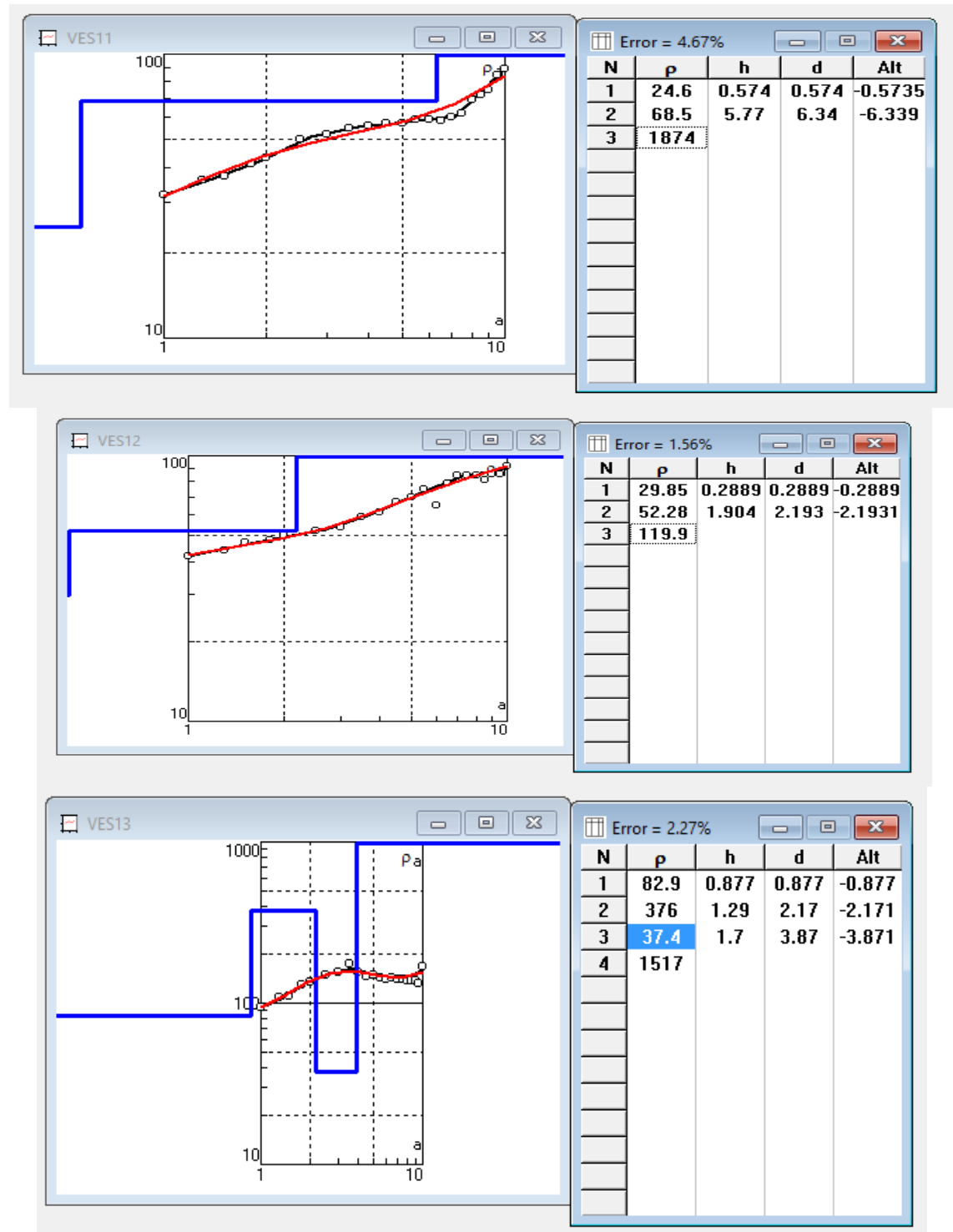

Fig. 7: Apparent resistivity/geoelectric models at the study site (VES 1-13)

\subsection{ISORESISTIVITY AND ISOPACH MAPS}

The resistivity and depth values obtained for each of the thirteen VES stations were presented in the Isoresistivity map and Isopach maps to further study the resistivity and the corrosive nature of the subsurface soil of the site been investigated. (fig. 8 to 14 ).

Fig. 8 shows the isoresistivity map of the first layer in the study site. The figure shows that the resistivity values of the topsoil in the varies from 20 to $26 \Omega \mathrm{m}$, typical of clay and sandy clay. The resistivity tends to be increasing towards the southwestern part of the study area as a result of trending towards a more resistive zone believed to be sandy clay. The isopach map of first layer (fig. 9) also shows the increasing depth towards southwestern part and it ranges between 0.2 and $1.7 \mathrm{~m}$. As recommended this portion has to be excavated. 


\section{International Advanced Research Journal in Science, Engineering and Technology}

Vol. 5, Issue 11, November 2018

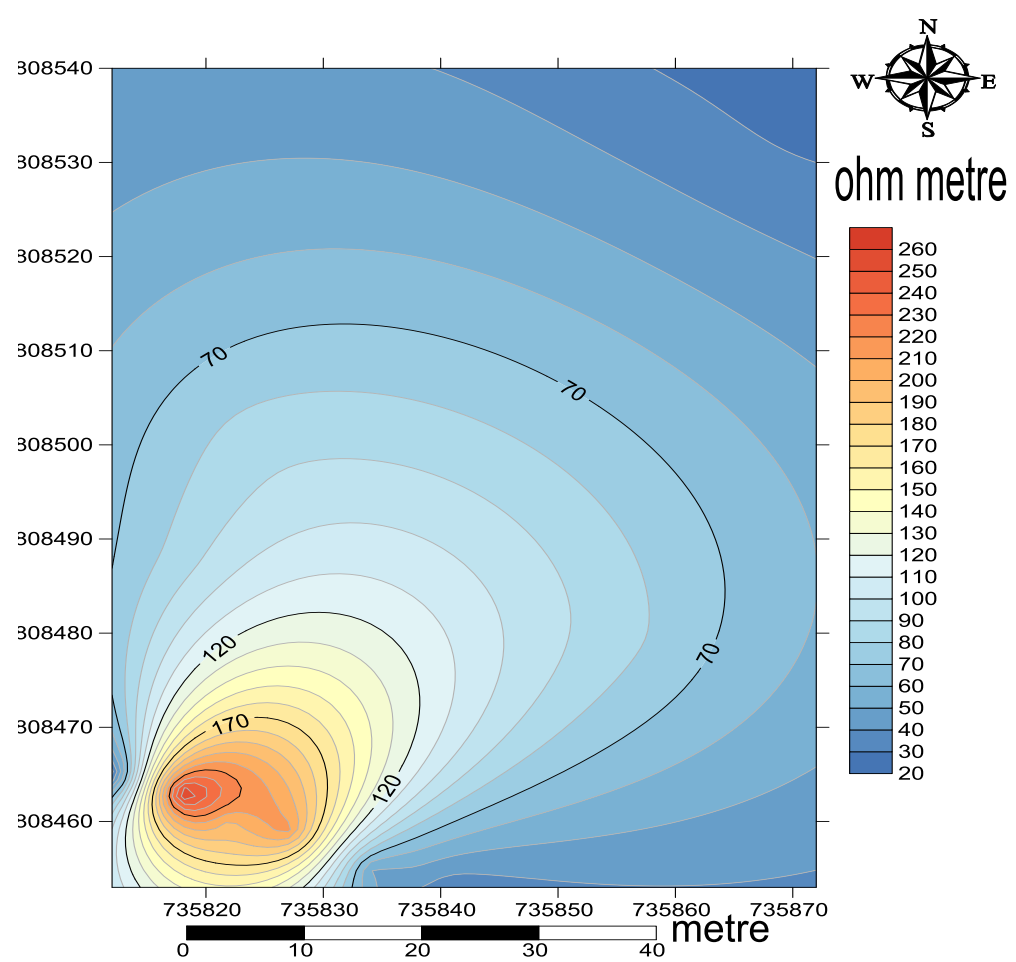

Fig. 8: Isoresistivity map of the first layer

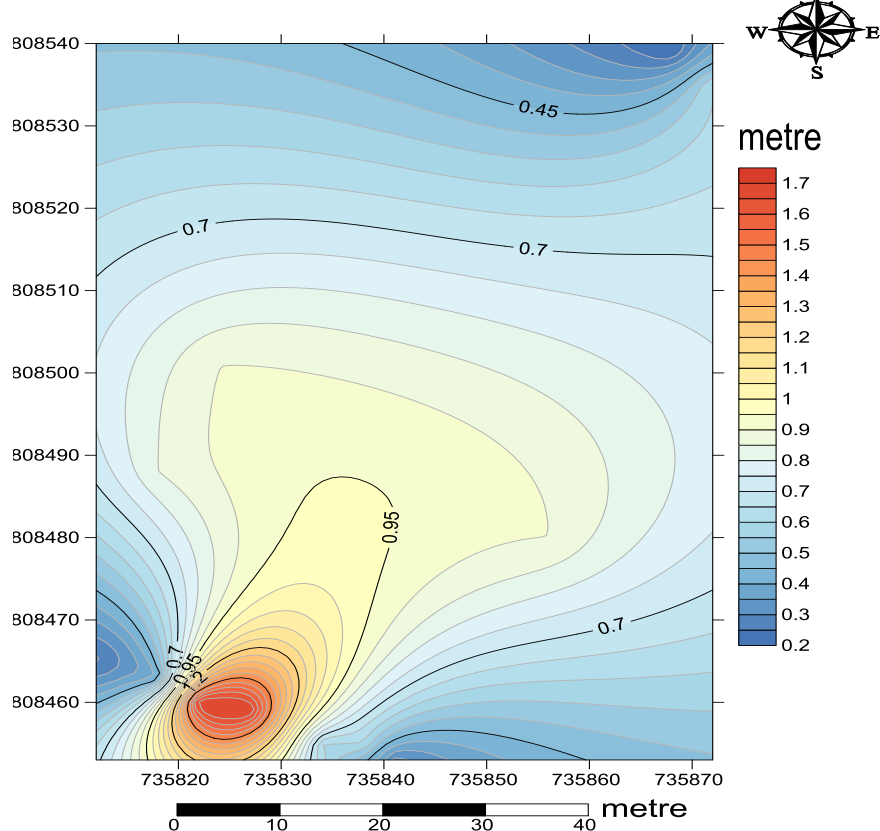

Fig. 9: Isopach map of the first layer

The isoresistivity map of the second layer (fig. 10) shows the resistivity values that range between 40 and $380 \mathrm{~m}$, with high resistive zones trending in the northwest-southeast direction, typical of clay, sandy clay and clayey sand. Also within the corrosive and non- corrosive zones. A zone of corrosive and mildly corrosive in the northeastern and southwestern parts of the site was also observed. The isopach map of the second layer, (fig.11) equally shows a depth value ranging between 1.5 to $9 \mathrm{~m}$, with a depth range of between 2.5 and $5 \mathrm{~m}$ occupying major parts of the study area. This justifies the recommendation of the second layer for the burial of the tank. Deeper depths are found in the small portion of the southwestern, southeastern and northeastern parts of the study site. 


\section{International Advanced Research Journal in Science, Engineering and Technology}

Vol. 5, Issue 11, November 2018

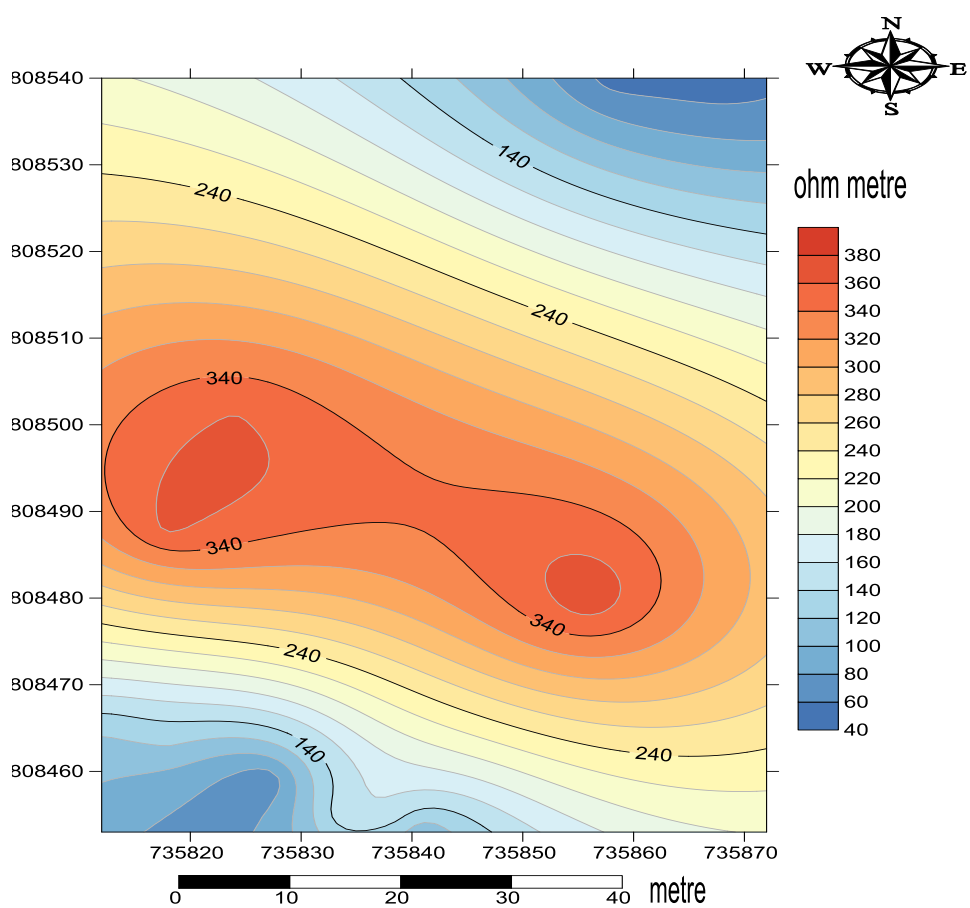

Fig. 10: Isoresistivity map of the second layer

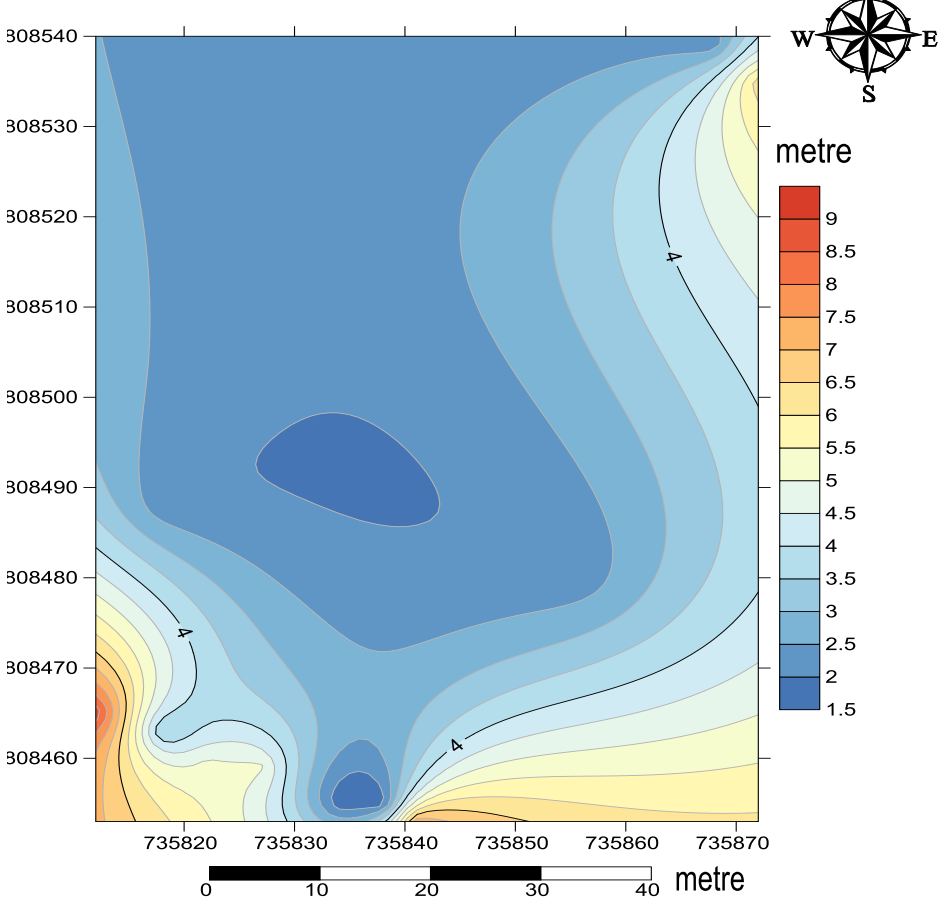

Fig. 11: Isopach map of the second layer

The isoresistivity map of the third layer (fig.12) shows that it has a resistivity values within the range of 0 and $700 \Omega \mathrm{m}$ which are within clay, sandy clay and clayey sand and still occupies the larger portion of the site, and a more resistive bedrock in the small portion of the northwestern part. The isopach map of the third (fig. 13) layer shows a depth which ranges between 0.2 and $5.2 \mathrm{~m}$. The larger portion of the site has a depth range of 2 to $5.2 \mathrm{~m}$ which further confirms the recommendation for the burial of the tank. The isopach maps of second and third layers confirms the choice of the depth between 2.0 and 6.3 as most favourable depth for the burial of the tank. 


\section{International Advanced Research Journal in Science, Engineering and Technology}

Vol. 5, Issue 11, November 2018

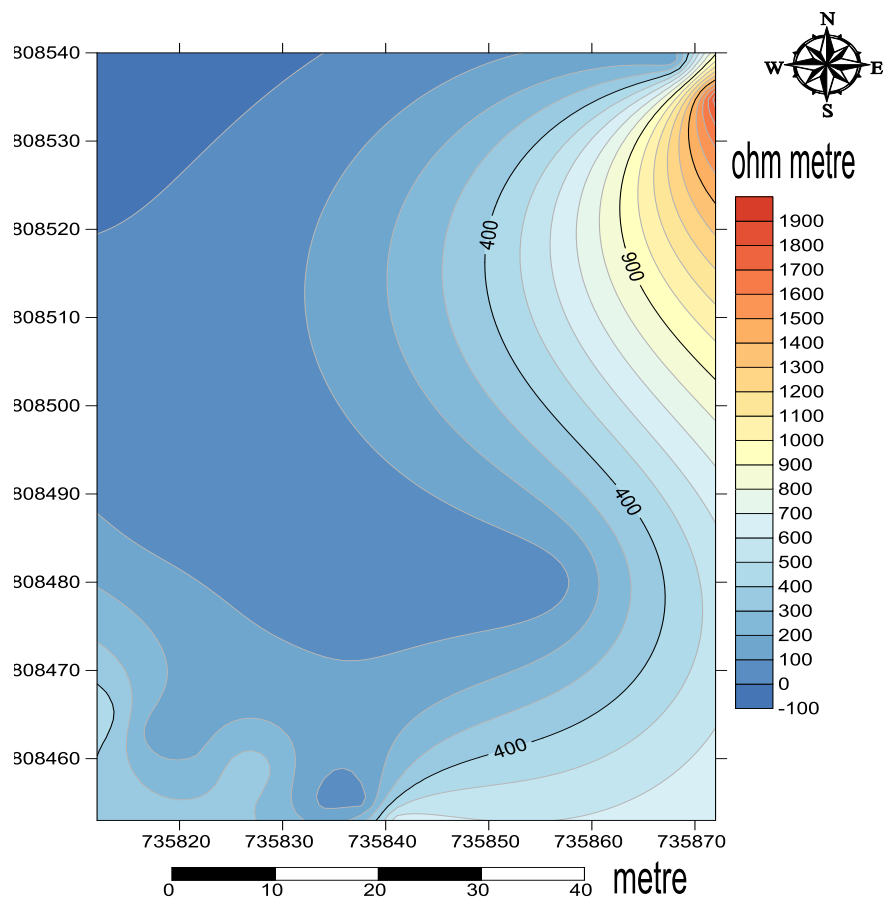

Fig. 12: Isoresistivity map of the third layer

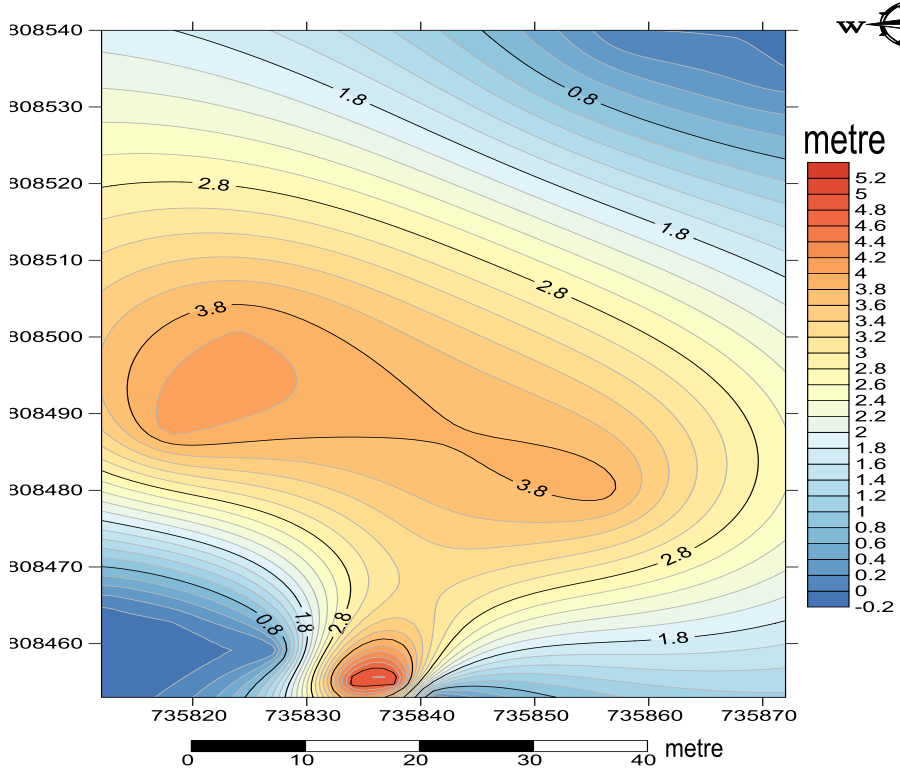

Fig. 13: Isopach map of the third layer

The isoresistivity map of the fourth layer shows its resistivity values approaching the basement whose depth values cannot be resolved.

Generally, the subsurface soil corrosivity status for the study site falls between corrosion and mildly corrosive zones (table 1), and lithologically between clay and clayey sand (table 2). The implication of this is that any buried metallic structure within the study site would still be subjected to corrosion and possibly rusting but the severity might not be much and that is why protective measure was suggested. Again, the recommended layers (based on resistivity values and depth values) falls within clay and clayey sand, and by the research conducted by [4] on the effect of clay and moisture content on soil-corrosion dynamic showed that high clay content soils present more packed particles and have less pore capacity for moisture (water) and gases (oxygen) diffusion than an open-type-soil such as sand/gravel, and then concluded that soils with high clay content are less corrosive. So based on this authority, the study finally concluded that the tank be buried between second layer (resistivity values between 52 and $376 \Omega \mathrm{m}$, depth range 


\section{International Advanced Research Journal in Science, Engineering and Technology}

Vol. 5, Issue 11, November 2018

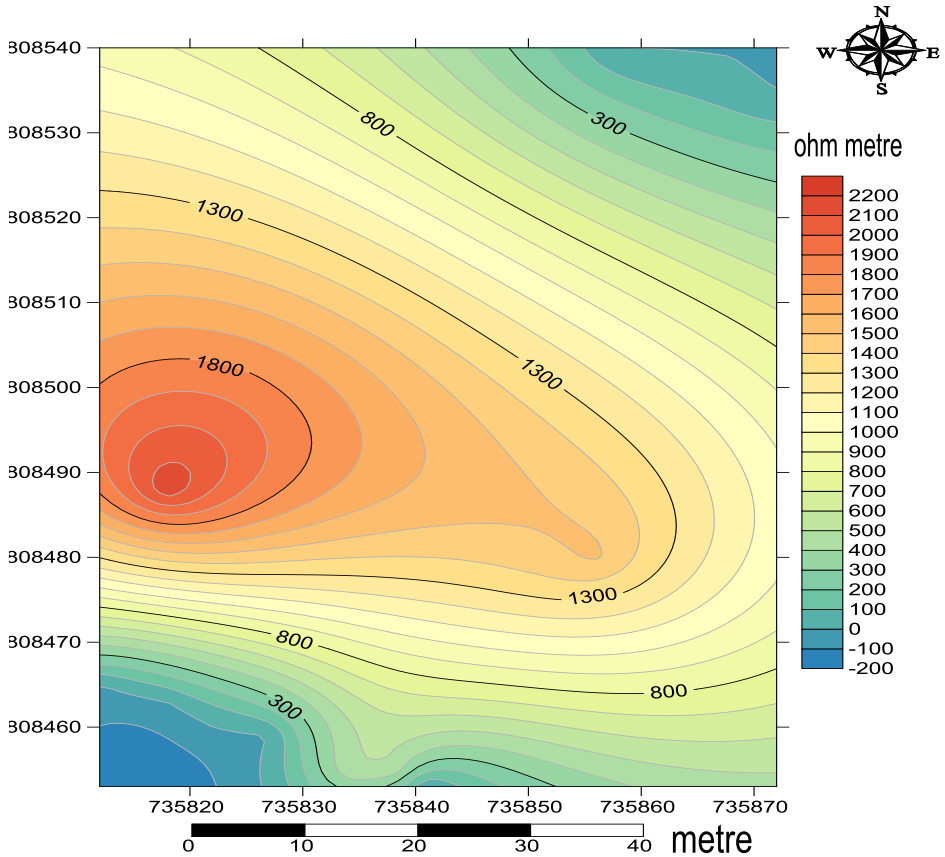

Fig. 14: Isoresistivity map of the fourth layer

between 1.7 and $8.9 \mathrm{~m}$ ), and third layer (resistivity values between 37 and $1874 \Omega \mathrm{m}$ with depth range between 3.9 and $5 \mathrm{~m}$ ) but the tank should equally be coated with some protective coating materials like bitumen.

\section{CONCLUSION}

It has been established in this study that electrical resistivity method is useful in determining the corrosivity status of the subsurface soils. The resistivity values and depth values were used in the categorization of the subsurface soil zones into various corrosivity statuses and also used to generate isoresistivity and the isopach maps which were further used in the categorization. Generally, the subsurface soil corrosivity status falls between corrosion and mildly corrosive zones (table 1), and lithologically between clay and clayey sand (table 2). The study finally concluded that the tank be buried between second layer (resistivity values between 52 and $376 \Omega \mathrm{m}$, depth range between 1.7 and $8.9 \mathrm{~m}$ ), and third layer (resistivity values between 37 and $1874 \Omega \mathrm{m}$ with depth range between 3.9 and $5 \mathrm{~m}$ ) but the tank should equally be coated with some protective coating materials like bitumen.

\section{REFERENCES}

[1] I.B. Osazuwa and E. ChiiChii, "Two-dimensional electrical resistivity survey around the periphery of an artificial lake in the precambriam basement complex of northern Nigeria". International journal of physical sciences, Vol.5 no.3 pp. 238-245, 2010

[2] K.S. Lim, Y. Nordin, R.O. Siti, N.F. Siti, and M.N. Norhazilan, "The Relationship between soil resistivity and corrosion growth in tropical Region". The Journal of corrosion science and Engineering. Vol.16, Reprint54, pp. 1-11, 2013

[3] Q. Fei, J. Changliang, C. Xinhua, W. Qiang, W. Juhong, H. Rui, (2018) :Effect of soil moisture content on corrosion behavior of X70 steel.Int. J. Electrochem.Sc, 13 pp. 1603-1613, 2018

[4] N. Yahaya, K.S. Lim, N.M. Noor, S.R. Othman, A. Abdullah, “Effects of clay and misture content on soil-corrosivity”. Malaysian Journal of Civil Engineering 23(1), pp. 24-32, 2011

[5] S. A. Ngah and T.K.S. Abam, "Shallow Resistivity Measurements for Subsoil Corrosivity Evaluation in Port Harcourt Metropolis, Nigeria". International Journal of Science and Technology. Volumes 3, No.2, pp. 85-91. (2014)

[6] K.O.,Ozegin, E.C. Okolie, and A. Oseghale, “Assessment of subsurface corrosivity severity using electrical resistivity methods in Igara, Edo state, Nigeria". International Journal of Engineering research and Applications (IJERA) Vol.1, issue 4, pp. 2055-2061, 2014

[7] W. Shengrang, D. Cuiwei, L. Xiaogang, L. Zhiyong, Z. Min, Z. Dawei, "Field corrosion characterization of soil corrosion of X70 pipeline steel in a red clay soil". Progress in Natural science: Materials international 25 (2015) pp. 242-250.

[8] O.G. Bayowa and N.S. Olayiwola, "Electrical resistivity investigation for Topsoil Thickness, Competence and Corrosivity Evaluation: A case study from Ladoke Akintola University of Technology, Ogbomoso, Nigeria". $20152^{\text {nd }}$ International Conference on Geological and Civil engineering. IPCBEE Vol.80 (2015) LACSIT press, Singapore. DOI: 10.7763/IPCBEE, 2015.v80.11

[9] Y. Nordin, M.N. Norhazilan, R.O.,Siti, K. S.,Lim, and M.D. Mazura, "New Technique in soil-corrosion study of underground pipeline”. Journal of Applied Sciences, Vol.11, No.9 (2011) pp. 1510-1518.

[10] C.O. Cyril, “ 2D Resistivity imaging and Geotechnical investigation of structural collapsed Lecture Theatre in Adekunle Ajasin University, AkungbaAkoko, Southwestern, Nigeria". Environmental Research, Engineering and Management,No. 3 (69), pp. 49-59, 2014

[11] D.A. Otekpen, "Application of electrical resistivity method in examination of subsoil corrosion at a proposed filling station". An Unpublished undergraduate Thesis submitted to the Department of Applied Geophysics, The Federal University of Technology, Akure - Nigeria, 2018

[12] M.A. Rahaman, "Review of the geology of southwestern Nigeria". In Geology of Nigeria $2^{\text {nd }}$ Edition (Kogbe, C.a., ed), Rock view (Nig.) Ltd.,Jos Nigeria, 1989 